\title{
MORPHOMETRIC STUDY OF THE NUTRIENT FORAMINA IN DRY HUMAN RADIUS BONES OF TELANGANA REGION
}

\author{
Naveen Kumar. B ${ }^{1}$, Jayashree. A ${ }^{* 2}$, Udaya Kumar ${ }^{3}$, Ramya Sree. A 4 .
}

${ }^{1}$ Department of Anatomy, Assistant Professor, Department of Anatomy, Mamata Medical College, Khammam, Talangana, India.

*2 Department of Anatomy, Associate Professor, Malla Reddy Medical College for Women, Hyderabad, Talangana, India.

${ }^{3}$ Associate Professor, Department of Anatomy, Mamata Medical College, Khammam, Talangana, India.

${ }^{4}$ Assistant professor, Department of Anatomy, Mamata Medical College, Khammam, Talangana, India.

\section{ABSTRACT}

Background: Bone formation, growth and its vitality necessitates blood supply. Nutrient artery is the key source of blood supply to the long bone apart from the other important sources like periosteal, metaphyseal and epiphyseal arteries. Nutrient foramina allows nutrient artery. Typically, the direction of the nutrient foramina is towards the elbow joint in radius, away from its growing end. Knowledge of foramen index, number, direction and size of the nutrient foramina assists the surgeon to take an exact section of bone in case of bone resection and transplantation techniques.

Aim: The aim of the present study is to determine the number, position, size, direction of the nutrient foramina and the Foramen Index of the human dry radius bones

Materials and Methods: In the present study, 91 right sided and 88 left sided radius bones of unknown age and sex were taken into consideration from the department of anatomy, Mamata Medical College, Khammam, Telanagana.

Results: Average length of the radius on the right side was observed to be $23.72 \pm 1.93 \mathrm{~cm}$ and on left side 23.35 $\pm 1.75 \mathrm{~cm}$. The foramen index on right side was $34.92 \pm 4.97 \mathrm{~cm}$ where as on the left side $34.79 \pm 4.43 \mathrm{~cm}$. The nutrient foramen was directed towards the proximal end of radius in all the bones studied. Most of the foramen were observed on the anterior surface of the bone. Nutrient foramina was found to be absent in 4 right sided and 3 left sided bones.

Conclusion: This study may add to the present statistical data available on foramen index, number of foramen and their location in the population of Telangana region, during recent orthopaedic techniques like bone resection and transplantation.

KEY WORDS: Nutrient foramina, radius, foramen index, nutrient artery.

Address for Correspondence: Dr. Jayashree Anagani, C/o Naveen Kumar. N, H. No. 4-1-138, Rotary Nagar, Khammam. Telangana - 507002, India. Mobile No: 09133000191

E-Mail: jayashree.anagani@gmail.com

Access this Article online

Quick Response code

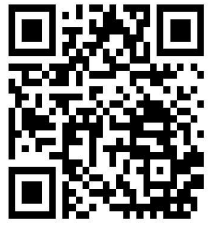

DOI: $10.16965 /$ ijar.2018.135

Journal Information

International Journal of Anatomy and Research

ICV for 2016 ISSN (E) 2321-4287 | ISSN (P) 2321-8967

90.30

https://www.ijmhr.org/ijar.htm

DOI-Prefix: https://dx.doi.org/10.16965/ijar

(cc) $\mathrm{Br}-\mathrm{kt}-\mathrm{si}$

\section{Article Information}

Received: 08 Feb 2018

Peer Review: 08 Feb 2018

Revised: None
Accepted: 07 Mar 2018

Published (O): 05 Apr 2018

Published (P): 05 Apr 2018 


\section{INTRODUCTION}

Bone formation, growth and its vitality necessitates blood supply. Nutrient artery is the key source of blood supply to the long bone apart from the other important sources like periosteal, metaphyseal and epiphyseal arteries. According to Trueta [1], nutrient artery supplies about $80 \%$ of blood to the growing long bone, in whose absence the peri-osteal arteries take active role to nourish the bone. Nutrient foramina allows nutrient artery along with the corresponding peripheral nerve to enter the bone at an angulation [2-5]. Typically, the direction of the nutrient foramina is towards the elbow joint in radius, away from its growing end [6]. The location, direction and number of nutrient foramina usually do not change with age or length of the bone, however, variations in the location, direction and number of nutrient foramina has been reported [7-9].

Knowledge of foramen index, number, direction and size of the nutrient foramina assists the surgeon to take an exact section of bone in case of bone resection and transplantation techniques.

Aim: The aim of the present study is to determine the number, position, size, direction of the nutrient foramina and the Foramen Index of the human dry radius bones

\section{MATERIALS AND METHODS}

Clean and dried human radius bones were obtained from the department of Anatomy, Mamata Medical College, Khammam, Telangana. In the present study, 91 right sided and 88 left sided radius bones of unknown age and sex were taken into consideration. Bones with pathological changes were omitted from the study.

Length of the bone was calculated by an osteometric board. Total length was calculated as the distance between the proximal aspect of the head of the radius and the most distal aspect of the styloid process. Foramen index (FI) was calculated using the formula:

$\mathrm{FI}=(\mathrm{DNF} / \mathrm{TL}) \times 100$ (Hughes [10], Shulman [7]). $\mathrm{DNF}=$ the distance from the proximal end of the bone to the nutrient foramen.

$\mathrm{TL}=$ total bone length.
Hand lens was used to observe the nutrient foramina. Size of foramina was measured using syringe needles of various gauzes. Foramina of size less than 24 gauze were not taken into account.

a) Size of the 18 gauze needle was considered to be between $1.27 \mathrm{~mm}$ or more [i.e $>1.27 \mathrm{~mm}$ ]. b) Size of the 20 gauze needle was considered to be between $0.90 \mathrm{~mm}$ and $1.27 \mathrm{~mm}$ [i.e $>0.90 \mathrm{~mm}$ to $<1.27 \mathrm{~mm}$.

c) Size of the 22 gauze needle was considered to be between $0.71 \mathrm{~mm}$ and $0.90 \mathrm{~mm}$ [i.e > $0.71 \mathrm{~mm}$ to $<0.90 \mathrm{~mm}$ ].

d) Size of the 24 gauze needle was considered to be between $0.55 \mathrm{~mm}$ and $0.71 \mathrm{~mm}$ [i.e > $0.55 \mathrm{~mm}$ to $<0.71 \mathrm{~mm}$ ].

\section{RESULTS}

\section{Direction of the nutrient foramina:}

In all the bones of both right and left side, the nutrient foramen were directed proximally.

\section{Incidence of nutrient foramen:}

Out of 91 right sided bones, the nutrient foramina (of size above 24 gauze) were not at all found in the shaft of four radius bones. Only one bone showed two foramina, all the other bones have single nutrient foramina. Whereas on the left side, out of 88 bones, 3 bones are found without nutrient foramina, four bones showed two foramen and the remaining bones showed single nutrient foramina. (Table No.2) (Fig 1).

Total length of the bone, distance from the upper end to proximal nutrient foramina and formen index are shown in the Table No.1. Segmental position and location of nutrient foramen on the bone and the size of foramina are shown in the Table No. 3, 4 \& 5. (Fig No. 2, 3,4 \& 5).

Table 1: showing the length of the bone, distance of the proximal nutrient foramina from the upper end and foramen index.

\begin{tabular}{|c|c|c|c|c|c|c|}
\hline & \multicolumn{2}{|c|}{ Total Length Of The Bone } & \multicolumn{2}{|c|}{$\begin{array}{c}\text { Distance From Upper End To } \\
\text { NF }\end{array}$} & \multicolumn{2}{|c|}{ Foramen Index } \\
\hline & Median & Mean With SD & Median & Mean With SD & Median & Mean With SD \\
\hline $\begin{array}{l}\text { RIGHT } \\
(n=91)\end{array}$ & 24 & $23.72 \pm 1.93$ & 8 & $8.26 \pm 1.18$ & 33.91 & $34.92 \pm 4.97$ \\
\hline $\begin{array}{l}\text { LEFT } \\
(n=88)\end{array}$ & 23.75 & $23.35 \pm 1.75$ & 8.1 & $8.12 \pm 1.18$ & 34.39 & $34.79 \pm 4.43$ \\
\hline
\end{tabular}

$\mathrm{n}=$ total number of bones, $\mathrm{SD}=$ standard deviation, $\mathrm{NF}=$ Nutrient foramina 
Table 2: Showing incidence of nutrient foramen.

$\mathrm{N}=$ total no. of of bones

\begin{tabular}{|c|c|c|c|c|c|c|}
\hline & \multicolumn{3}{|c|}{ Right (N = 91) } & \multicolumn{3}{c|}{ left (N = 88) } \\
\hline No. of foramina & 0 & 1 & 2 & 0 & 1 & 2 \\
\hline No.of bones & 4 & 86 & 1 & 3 & 81 & 4 \\
\hline Percentage & $4.39 \%$ & $94.51 \%$ & $1.09 \%$ & $3.41 \%$ & $92.05 \%$ & $4.55 \%$ \\
\hline
\end{tabular}

Table 3: Showing the segmental position of nutrient foramen.

$\mathrm{N}=$ total no of bones, $\mathrm{NF}=$ no. of foramina in each segment

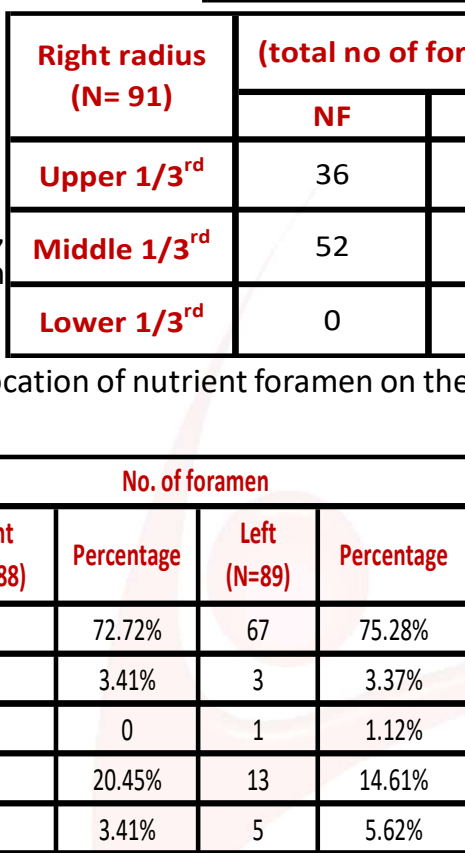

Table 4: Showing the location of nutrient foramen on the bone.

\begin{tabular}{|c|c|c|c|c|}
\hline \multirow{2}{*}{ Location of foramina } & \multicolumn{4}{|c|}{ No. of foramen } \\
\cline { 2 - 5 } & $\begin{array}{c}\text { Right } \\
(\mathrm{N}=88)\end{array}$ & Percentage & $\begin{array}{c}\text { Left } \\
(\mathrm{N}=89)\end{array}$ & Percentage \\
\hline Anterior surface & 64 & $72.72 \%$ & 67 & $75.28 \%$ \\
\hline Posterior surface & 3 & $3.41 \%$ & 3 & $3.37 \%$ \\
\hline Lateral surface & 0 & 0 & 1 & $1.12 \%$ \\
\hline Interosseous border & 18 & $20.45 \%$ & 13 & $14.61 \%$ \\
\hline Anterior border & 3 & $3.41 \%$ & 5 & $5.62 \%$ \\
\hline
\end{tabular}

Table 5: Showing the size of the nutrient foramen.

\begin{tabular}{|c|c|c|c|c|}
\hline $\begin{array}{c}\text { Size of the } \\
\text { foramen }\end{array}$ & $\begin{array}{c}\text { Right } \\
(\mathrm{N}=88)\end{array}$ & Percentage & $\begin{array}{c}\text { Left } \\
(\mathrm{N}=89)\end{array}$ & Percentage \\
\hline$\geq 1.27 \mathrm{~mm}$ & 15 & $17.05 \%$ & 7 & $7.87 \%$ \\
\hline $\begin{array}{c}\geq 0.90 \mathrm{~mm} \text { to } \\
<1.27 \mathrm{~mm}\end{array}$ & 20 & $22.73 \%$ & 16 & $17.98 \%$ \\
\hline $\begin{array}{c}\geq 0.71 \mathrm{~mm} \text { to } \\
<0.90 \mathrm{~mm}\end{array}$ & 35 & $39.77 \%$ & 16 & $17.98 \%$ \\
\hline $\begin{array}{c}\geq 0.55 \mathrm{~mm} \text { to } \\
<0.71 \mathrm{~mm}\end{array}$ & 18 & $20.45 \%$ & 50 & $56.17 \%$ \\
\hline
\end{tabular}

$\mathrm{N}=$ total no. of foramen

Table 6: Showing the comparison of segmental position of nutrient foramen by various authors.

\begin{tabular}{|c|c|c|c|}
\hline Author & $\begin{array}{c}\text { Upper } \\
1 / 3^{\text {rd }}\end{array}$ & $\begin{array}{c}\text { Middle } \\
1 / 3^{\text {rd }}\end{array}$ & $\begin{array}{c}\text { Lower } \\
1 / 3^{\text {rd }}\end{array}$ \\
\hline Anusha et al. [16] & $38.50 \%$ & $61.50 \%$ & - \\
\hline Anjana et al. [17] & $76 \%$ & $24 \%$ & - \\
\hline Udaya sree et al. [18] & $15.38 \%$ & $84.61 \%$ & - \\
\hline Bichitrananda et al. [29] & $24.32 \%$ & $75.67 \%$ & - \\
\hline Pramod et al. [24] & $66 \%$ & $34 \%$ & - \\
\hline Patel SM et al. [25] & $42.50 \%$ & $57.50 \%$ & - \\
\hline Solanke et al. [27] & $22.50 \%$ & $72.50 \%$ & - \\
\hline Ukoha et al. [28] & $57.10 \%$ & $42.90 \%$ & - \\
\hline Present study & $36.16 \%$ & $63.82 \%$ & \\
\hline
\end{tabular}

Fig. 1: Showing two nutrient foramen.

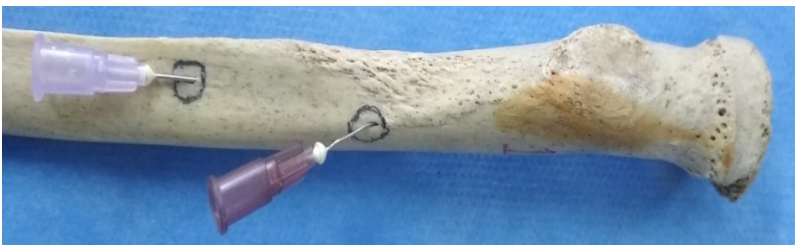

Table 7: Showing the comparison of number of nutrient foramen observed by various authors.

\begin{tabular}{|c|c|c|c|}
\hline Author & 0 foramina & 1 foramina & 2 foramen \\
\hline Bichitrananda et al. [29] & - & $97.29 \%$ & $2.70 \%$ \\
\hline Emine Kizilkanat et al. [19] & - & $98.92 \%$ & $1.07 \%$ \\
\hline Mani Arora et al. [20] & - & $98.20 \%$ & $1.80 \%$ \\
\hline Periera et al. [23] & - & $99.36 \%$ & $0.63 \%$ \\
\hline Pramod et al. [24] & - & $97 \%$ & $3 \%$ \\
\hline Patel SM et al. [25] & - & $100 \%$ & - \\
\hline Sharma et al. [26] & $5 \%$ & $80 \%$ & $15 \%$ \\
\hline Solanke et al. [27] & $5 \%$ & $92.50 \%$ & $2.50 \%$ \\
\hline Ukoha et al. [28] & $32 \%$ & $68 \%$ & - \\
\hline Anusha et al. [16] & $2 \%$ & $92 \%$ & $6 \%$ \\
\hline Meenakshi et al. [21] & $4.16 \%$ & $94.44 \%$ & $1.39 \%$ \\
\hline Murlimanju et al. [22] & $4.16 \%$ & $94.44 \%$ & $1.39 \%$ \\
\hline Present study & $3.90 \%$ & $93.28 \%$ & $2.82 \%$ \\
\hline
\end{tabular}

Fig. 2: Showing nutrient foramen on the anterior surface of radius.

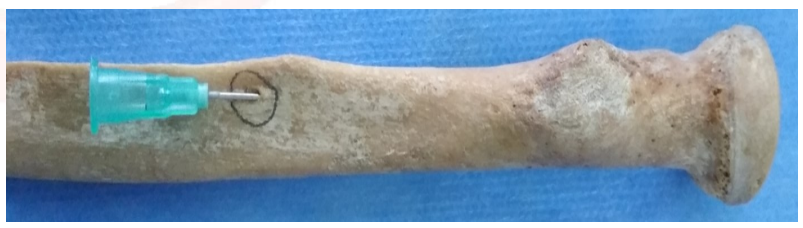

Fig. 3: Showing nutrient foramen on the posterior surface of radius.

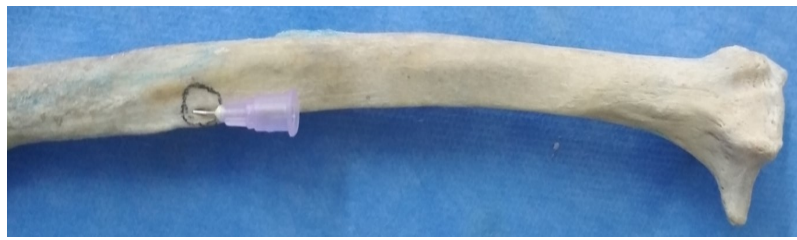

Fig. 4: Showing nutrient foramen on the anterior boarder of radius.

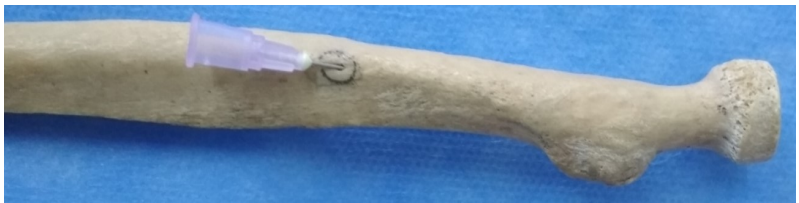

Fig. 5: Showing nutrient foramen on the interosseous boarder of radius

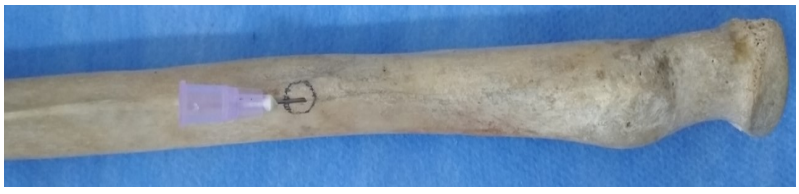




\section{DISCUSSION}

Developmentally, a periosteal bud excavates the newly formed bone to allow the nutrient artery to enter the calcified matrix, whose opening later remains as Nutrient canal [11]. Nutrient artery is the chief source of blood to long bones, about seventy to eighty percent during growth and development, along with the periosteal, diaphyseal and epiphyseal arteries [12].

Growing end of a long bone can be determined by the direction of nutrient foramina. The hemodynamic flow of blood from cephalic to caudal direction forces the nutrient artery to course caudally. Due to differential growth of the two ends of a long bone, the nutrient artery is directed away from the growing end [13].

However a few studies have shown that the direction of the nutrient foramina is at variance in mammals [14]. In the present study all the nutrient foramina are directed away from the growing end, towards proximal.

The position of the foramina was observed consistently on flexor surfaces $[14,15]$ as it is true even in case of the present study. The results in the present study (right radius: $72.72 \%$, Left radius: $75.28 \%$ )(table No. 4 ) are in consistent with the results of the other authors such as Anusha et al [16] (72.2\%), Anjana et al [17] (88\%), Udaya sree et al [18] (100\%), Emine Kizilkanat et al [19] (96.8\%), Mani arora [20] (77.98\%), Meenakshi et al [21](72.23\%), Murlimanju et al [22](72.23\%), Pereira et al [23] (73.2\%), Pramod et al [24] (91.3\%), Patel SM et al [25] (87.5\%), Sharma et al [26] (72.75\%), Solanke et al [27] (73.75\%), Ukoha et al [28] (91.4\%). As it is shown in the table no.1, 3 and 6 most of the foramina on radius are located in the middle third of the bone. In the present study the foramen index is $34.86 \pm 4.7 \mathrm{~cm}$, with the average length of bone as $23.48 \pm 2.8 \mathrm{~cm}$, indicating the location of the foramina in middle third of the bone. However Anjana et al [17], Pramod et al [24] and Ukoha et al [28] observed that the nutrient foramina in radius are mostly located in the upper one third of the bone. No foramina are found in the lower one third.

As stated in the table no. 7 the present study showed single nutrient foramen in more than $90 \%$ of the bones similar to the other previous studies. Present study did not show any nutrient foramina in $3.9 \%$ of bones corresponding to the results of Sharma et al [26], Solanke et al [27], Anusha et al [16], Meenakshi et al [21] and Murlimanju et al [22], but a study by Ukoha et al [28] in 50 radii of Nigeria population reported that only $68 \%$ bones have single nutrient foramina and $32 \%$ of bones are without any nutrient foramina.

The knowledge of position of nutrient foramina is important in case of orthopaedic techniques like fracture repair, bone graft transplantation and resection. This knowledge also serves the surgeon to be careful enough during surgical procedures to prevent post surgical fracture non-union

\section{CONCLUSION}

In the present study the average length of the bone and foramina of the size e"1.27 mm are more on the right side when compared to the left side. The foramina are located mostly in the middle third of the bone on the anterior surface with mean foramen index of $34.86 \pm 4.7$. The results of this study, which are mostly in consistent with the other studies, may add to the present statistical data available, especially in the population of Telangana region.

\section{ACKNOWLEDGEMENTS}

Special thanks to Dr. K R S Prasad Rao and Dr. Vinay for their valuable suggestions. Authors acknowledge the immense help received from the scholars whose articles are cited and included in references of this manuscript. The authors are also grateful to authors / editors / publishers of all those articles, journals and books from where the literature for this article has been reviewed and discussed.

\section{Conflicts of Interests: None}

\section{REFERENCES}

[1]. Trueta, J. Blood supply and the rate of healing of tibial fractures. Clin. Orthop. Rel. Res., 1953;105:1126.

[2]. Lewis, O.J. The blood supply of developing long bones with special reference to the metaphyses. J. Bone Jt. Surg. 1956;38:928-933.

[3]. Brookes, M. Blood supply of long bones. Br. Med. J., 1963;2:1064- 5. 
[4]. Sendemir E., Cimen A. Nutrient foramina in the shafts of lower limb long bones: situation and number. Surg. Radiol. Anat. 1991;13:105 -108.

[5]. Gumusburun E., Yucel F., Ozkan Y., Akgun Z. A study of the nutrient foramina of lower limb long bones. Surg. Radiol. Anat. 1994;16:409-412.

[6]. Datta AK. Principles of general Anatomy. 6th ed. Kolkata, India: Current books international; 2010;75-77.

[7]. Shulman, S.S. Observations on the nutrient foramina of the human radius and ulna. Anat. Rec.1959; 134:685-697.

[8]. Patake SM, Mysorekar VR. Diaphysial nutrient foramina in human metacarpals and metatarsals. J Anat 1977;124:299-304.

[9]. Mysorekar, V.R. Diaphysial nutrient foramina in human long bones. J. Anat. 1967;101:813-822.

[10]. Hughes $H$. The factors determining the direction of the canal for the nutrient artery in the long bones of mammals and birds. Acta Anat (Basel) 1952;15:261280.

[11]. Datta AK. The sclerous tissue. In: Principles of General anatomy, $6^{\text {th }}$ ed. Chapter 6, 2005; KP Basu publishing Co, Kolkata, 68-73.

[12]. Forriol Campos F, Gomez L, Gianonatti M, Fernandez R. A study of the nutrient foramina in human long bones. Surg Radiol Anat 1987; 9:251-255.

[13]. Mysorekar VR, Nandedkar AN. Diaphysial nutrient foramina in human phalanges. J Anat 1979; 128:315322.

[14]. Henderson RG. The position of the nutrient foramen in the growing tibia and femur of the rat. J Anat 1978; 125:593-599.

[15]. Longia, G.S., Ajmani, M.L., Saxena, S.K., Thomas, R.J. Study of diaphyseal nutrient foramina in human long bones. Acta Anat. (Basel) 1980;107:399-406.

[16]. Anusha P, Naidu MP. A study on the nutrient foramina of long bones. Jour of Med Sc \& Tech; 2013;(3):150157.

[17]. Anjana mathur, Manish D sharma. Study of Nutrient Foramina of Fibula with Other Long Bones: A Central Rajasthan Study. Int J Med Res Prof. 2016;2(3):155-57.

[18]. Udayasree L, Ravindranath G, Maheswari KB, et al. Anatomical study of nutrient foramina in dried human upper limb bones and their clinical significance. J. Evolution Med. Dent. Sci. 2017;6(2):110113, DOI: $10.14260 /$ Jemds/2017/28

[19].Emine Kizilkanata, Neslihan Boyana, Esin T. Ozsahina, Roger Soamesb, Ozkan Oguza, Location, number and clinical significance of nutrient foramina in human long bones, Ann Anat 2007;189:87-95.
[20]. Mani Arora, Morphometric study of nutrient foramina of human radii and their surgical importance, Indian Journal of Basic \& Applied Medical Research; December 2011;1(1):86-91.

[21].Meenakshi Parthasarathy, Sharmadhakl, Pushpalatha.M, Dr.Parthasarathy Kr, Krishnarjun P, Reddy Priyatham Tulasi, Morphological And Topographical Anatomy of Nutrient Foramina In Human Upper Limb Long Bones And Their Surgical Importance; IOSR Journal of Dental and Medical Sciences; 2016;15(8) Ver. X:80-85.

[22]. B. V. Murlimanju, K. U. Prashanth, Latha V. Prabhu, Vasudha V. Saralaya, Mangala M. Pai, Rajalakshmi Rai; Morphological and topographical anatomy of nutrient foramina in human upper limb long bones and their surgical importance; Rom J Morphol Embryol 2011;52(3):859-862.

[23]. Pereira, G. A. M.; Lopes, P. T. C.; Santos, A. M. P. V. \& Silveira, F. H. S. Nutrient foramina in the upper and lower limb long bones: Morphometric study in bones of Southern Brazilian adults. Int. J. Morphol., 2011;29(2):514-520.

[24]. Pramod Rangasubhe, Sheela Sivan, A study of nutrient foramina in dry adult radii of south indian subjects, National Journal of clinical anatomy, 2014;3(2):71-75.

[25]. Patel SM, Vora RK. Anatomical study of nutrient foramina in long bones of human upper limbs. IAIM, 2015;2(8):94-98.

[26]. Sharma T, Wadhwa A. Morphological Variations of Nutrient Foramina in upper limb long bones. Int J Med and Dent Sci 2013;2(2):177-181.

[27]. Solanke KS, Bhatnagar R, Pokhrel R. Number and position of nutrient foramina in humerus, radius and ulna of human dry bones of Indian origin with clinical correlation. OA Anatomy 2014 Feb 01;2(1):4.

[28]. Ukoha Ukoha Ukoha, Kosisochukwu Emmanuel Umeasalugo, Henry C Nzeako, Damian N Ezejindu, Obioma C Ejimofor, Izuchukwu F Obazie; A Study Of Nutrient Foramina In Long Bones Of Nigerians; National Journal Of Medical Research 2013;3:306-308

[29]. Bichitrananda Roul, Meena Goyal; A Study Of Nutrient Foramen In Long Bones Of Superior Extremity In Human Being; International Journal of Current Research in Life Sciences 2015;4(4):198-200.

How to cite this article:

Naveen Kumar. B, Jayashree. A, Udaya Kumar P, Ramya Sree. A. MORPHOMETRIC STUDY OF THE NUTRIENT FORAMINA IN DRY HUMAN RADIUS BONES OF TELANGANA REGION. Int J Anat Res 2018;6(2.1):5122-5126. DOI: 10.16965/ijar.2018.135 